\title{
ESCULTORES ITALIANOS EN ESPAÑA A COMIENZOS DEL SIGLO XVIII: NOVEDADES SOBRE DOMENICO LEMICO Y DOMENICO GRASSELLI*
}

\author{
LETIZIA GAETA ${ }^{1}$ \\ Università del Salento \\ MANuel García LuQue ${ }^{2}$ \\ Universidad de Sevilla
}

\begin{abstract}
La instalación en Andalucía del escultor napolitano Domenico Lemico y del escultor veneciano Domenico Grasselli a comienzos del siglo XVIII constituye un episodio olvidado en la historia de las relaciones artísticas entre España e Italia. En este artículo reconstruimos la trayectoria ibérica de ambos artistas mediante el estudio de fuentes inéditas y la atribución de nuevas obras.

Palabras clave: Domenico Lemico; Domenico Grasselli; Barroco; Escultura; Nápoles; Venecia; Sevilla; siglo XVIII.
\end{abstract}

ITALIAN SCULPTORS IN SPAIN AT THE BEGINNING OF THE EIGHTEENTH CENTURY:

NEW INFORMATION ABOUT DOMENICO LEMICO AND DOMENICO GRASSELLI

The settlement in Andalusia of the Neapolitan sculptor Domenico Lemico and the Venetian sculptor Domenico Grasselli at the beginning of the eighteenth century constitutes a forgotten episode in the history of artistic exchanges between Spain and Italy. In this paper, the Iberian career of both artists is reconstructed through the study of unpublished sources and the attribution of some new works.

Key words: Domenico Lemico; Domenico Grasselli; Baroque; Sculpture; Naples; Venice; Seville; eighteenth century.

Cómo citar este artículo / Citation: Gaeta, Letizia / García Luque, Manuel (2019): "Escultores italianos en España a comienzos del siglo XVIII: novedades sobre Domenico Lemico y Domenico Grasselli”. En: Archivo Español de Arte, vol. 92, núm. 368, Madrid, pp. 381-396. https://doi.org/10.3989/aearte.2019.24.

\section{La estancia de Domenico Lemico en Sevilla tras el virreinato del duque de Medinaceli en Nápoles}

Si la historia del arte es fundamentalmente la historia de las relaciones artísticas, la existente entre Nápoles y España es también la historia de un creciente enriquecimiento historiográfico

\footnotetext{
* Este trabajo nace del intercambio de ideas entre ambos autores, pero por una cuestión de burocracia académica se hace constar que la primera parte sobre Lemico ha sido elaborada por Letizia Gaeta, mientras que la segunda corresponde a Manuel García Luque y ha sido realizada en el ámbito del proyecto "Barroco entre dos mundos: relaciones y alternativas en la escultura andaluza e hispanoamericana entre 1700 y 1750" (HAR2017-83037-P).

1 letizia.gaeta@unisalento.it / ORCID iD: http://orcid.org/0000-0002-7697-8334.

2 mgluque@us.es / ORCID iD: http://orcid.org/0000-0001-9795-5679.
} 
entre las dos orillas del Mediterráneo. Entre los años sesenta y setenta del pasado siglo despegó una línea metodológica que, especialmente en lo que respecta al ámbito de la estatuaria en madera policromada, ha recibido un notable impulso en los últimos veinte años con la aparición de nuevas obras, artistas y documentos. A los estudios pioneros de José Crisanto López sobre la Escultura mediterránea y el escultor napolitano, asentado en Murcia, Nicola Salzillo (1672$1727)^{3}$, vinieron a sumarse los importantes trabajos de Elena Santiago y Margarita Estella sobre obras napolitanas en España - precisamente publicados en las páginas de Archivo Español de $\mathrm{Arte}^{4}$ - , que suministraron las bases para el desarrollo de posteriores estudios de corte filológico y sociológico, enriquecidos también con los nuevos enfoques historiográficos sobre la comitencia y sobre la recepción de la obra, en su vertiente coleccionista, que están constituyendo las líneas de investigación más relevantes, tanto en Italia como en España ${ }^{5}$.

El interés por la escultura en madera ha contribuido considerablemente a una mejor comprensión historiográfica de estas dinámicas, en especial en lo que respecta al descubrimiento de esculturas devocionales, por las que se mostraron particularmente atraídos los nobles españoles en la corte napolitana. Esta afición no siempre suscitó juicios positivos entre sus contemporáneos, al menos entre aquellos eruditos y "entendidos" cuyo gusto se orientaba hacia una cultura figurativa clasicista y selectiva. Lo demuestra el testimonio de Giovan Battista Pacichelli, agente farnesiano en Nápoles, conocido fundamentalmente por su obra Il regno di Napoli in prospettiva, que ilustró el cartógrafo "hispanicus" Francesco Diego de Silva y fue dada a las prensas entre 1692 y 1695, pese a que la edición no vio la luz hasta 1703. En una carta escrita desde Roma en 1693 y dirigida a Giacomo Saluzzo - en aquel momento estante en la capital partenopea-, Pacichelli nos brinda un primer y elocuente testimonio del gusto por la escultura en madera y los artífices que entonces estaban más a la moda. Su juicio se anticipa con mucho a las Vite que Bernardo de Dominici escribiría sobre los artistas napolitanos entre 1742 y 1745, una fuente imprescindible cuya fiabilidad para los hechos más cercanos al biógrafo ha sido reivindicada en los últimos años, y, como tal, oportunamente considerada por distintos investigadores españoles ${ }^{6}$. Vale la pena recordar las palabras del erudito Pacichelli para introducir la cuestión que nos interesa:

Giudichi pur ciascuno à suo piacere delle Scolture sagre in legno dè Sig. Aniello e Michele figliuoli del fù Gioseppe Perrone, dell'Ardia, e di codesti altri Virtuosi, e della loro Esquisitezza, ò pè muscoli ben'espressi, ò per la carnagione colorita al vivo, ò per la delicata Dentatura e Palato, Vivacità degli occhi nel Vetro, con le ciglia e capelli naturali, con le Vesti di seta giusta il decoro, ò di lana, e in parte riussite secondo le leggi, e consuetudini degli Ordini Regolari: cò Piedistalli d'intaglio dorato, e custoditi nell'Ebano sotto il cristallo, in modo che la Rappresentanza ecciti à divota memoria del Rappresentato. E ne vadan pure in casse numerose, à prezzo di sessanta, ottanta, e anche più di cento ducati à una regali ben ricevuti né palagi primari della Spagna [...] ma non si rende tributo à Prencipi, che col Metallo, ò col Marmo .

La dinámica y exuberante nobleza española asentada en la corte virreinal alimentó sin duda el mercado artístico de esculturas de madera, pero a menudo el deseo de los duques y condes era

\footnotetext{
3 López Jiménez, 1963: 1966.

4 Santiago Páez, 1967: Estella Marcos, 1973: 1976. Por la riqueza de argumentaciones propuestas por esta investigadora (referente en Italia para los estudios de escultura desde hace casi medio siglo) véase también Estella Marcos, 2007; 2015.

5 Aunque no es el momento de hacer una relación exhaustiva, se recuerdan aquí los trabajos de Borrelli, 1970: 2005. Gaeta 2007b: 2011. Casciaro, 2007: 2011. Pasculli Ferrara, 2007. A un nivel más general remitimos a los catálogos y congresos de los últimos años: Gaeta, 2007a. Casciaro/Cassiano, 2007. Leone de Castris, 2009; 2015. La abultada nómina de jóvenes investigadores hace imposible enumerarlos a todos, pero citaremos a Alonso Moral 2007; 2015; 2017. Di Liddo, 2008. Coiro, 2011; 2017.

${ }^{6}$ De la importancia de De Dominici, leído con una mirada desprejuiciada, se percató Elena Santiago, quien a partir de la Vita di Lorenzo Vaccaro localizó en la catedral de Toledo el extraordinario grupo argénteo de las Cuatro partes del mundo. También ha destacado su importancia Alonso Moral, 2007: 75.

${ }^{7}$ La fuente ha sido dada a conocer en relación con la escultura por Gaeta, 2007b: 201-202.
} 
el de adquirir esculturas en mármol, preferentemente antiguas, para trasladarlas a sus residencias españolas una vez terminado el mandato político. Las palabras de Pacichelli, además de ofrecer una cumplida descripción del envío a España de cajas con urnas, peanas, estatuas de tamaño natural y en formato "terzino", ponen de relieve una idea que no hay que perder de vista: para rendir tributo a la gran nobleza, para eternizar su memoria y magnificencia, resultaban indispensables las obras de arte realizadas en materiales preciados, es decir, en mármol y bronce.

Para arrojar algo de luz sobre el episodio artístico del que vamos a tratar, debemos remontarnos a la figura del virrey don Per Afán de Ribera (1509-1571), I duque de Alcalá y virrey de Nápoles entre 1559 y $1571^{8}$. Su pasión por las antigüedades le llevó a reunir una consistente colección de estatuas y restos arqueológicos para decorar su palacio sevillano, más tarde conocido como Casa de Pilatos. La colección, en parte donada por el papa Pío V, había estado anteriormente expuesta en el palacio real napolitano9. Los usos decorativos y celebrativos de estas antigüedades movieron al duque de Alcalá a encomendar unos trabajos de remodelación de los jardines y el palacio sevillano a Benvenuto Tortelli o Tortello, escultor y arquitecto activo en Nápoles desde los años sesenta del quinientos, que constituye un raro caso de artista dispuesto a trasladarse a otro país ${ }^{10}$.

No resulta fácil valorar la verdadera entidad de la colección de antigüedades reunida por Alcalá en Sevilla, teniendo en cuenta además que el corpus napolitano pudo llegar mermado por el asalto corsario que sufrió la embarcación en su viaje hacia Cartagena. Lleó estudió los pocos inventarios que han sobrevivido para hacerse una idea de las esculturas que quedaron distribuidas entre las logias, el patio principal y los jardines. El de 1588 hace referencia a la colección junto a elementos arquitectónicos, columnas, basas, inscripciones y capiteles. En él se mencionan también diez bustos y dieciocho estatuas, "quebradas" y de pequeño formato, que, como apunta el mencionado autor, tal vez no estuvieran pensadas para decorar los jardines. Otro inventario de 1751 -redactado en un momento de decadencia para el palacio, con una parte de la colección ya en Madrid- apenas se detiene a describir las piezas, reflejando una mera acumulación de mármoles ${ }^{11}$.

En 1989 fue publicado un importante documento que ha sido ignorado $-\mathrm{y}$ por tanto no se ha valorado- en los estudios sobre escultura napolitana y española ${ }^{12}$. El mismo hace emerger de la penumbra la figura de Domenico Lemico, quien el 8 de octubre de 1705 se presentaba como "maestro escultor de piedra, napolitano, rezidente en esta ciudad de Sevilla". Su declaración en primera persona, rubricada con su elegante firma, desvela un escenario fascinante que abre vías para ulteriores investigaciones sobre las relaciones entre Nápoles y España, más allá de los clásicos nombres manejados por la bibliografía especializada. A través de ella, Domenico Lemico afirmaba haber trabajado al servicio del "excelentissimo señor Duque de Medinaceli" en la "cassa Palacio", es decir, en la Casa de Pilatos. El comitente no es otro que Luis Francisco de la Cerda y Aragón (1660-1711), IX duque de Medinaceli, que había ocupado el cargo de virrey de Nápoles entre 1696 y 1702 sucediendo a su tío, el IX conde de Santisteban. Antes de llegar a la capital partenopea, Medinaceli había estado destinado en Roma como embajador ante la Santa Sede. Sus interes culturales, especialmente en el campo musical y literario, florecieron con la fundación de la Academia Palatina de Nápoles, donde el joven Giovan Battista Vico recitó la oración Delle cene sontuosi de' Romani, dando buena cuenta de cómo los intereses anticuarios se asociaban al esplendor y magnificencia propios de la vida cortesana ${ }^{13}$.

No poseemos documentación sobre eventuales traslados de nuevos materiales arqueológicos o esculturas modernas de Roma o Nápoles a Sevilla, pero gracias al documento exhumado por Martínez-Darve y Mata sabemos que en 1705 el maestro partenopeo había concluido la repara-

\footnotetext{
8 Sobre este asunto nos atenemos al trabajo de Lleó Cañal, 1998 (2017).

9 Lleó Cañal, 1998 (2017): 123.

10 Lleó Cañal, 2017. Sobre la anticomanía de los virreyes, véase Lleó Cañal, 2003. Checa Cremades, 2001.

11 Lleó Cañal, 1998 (2017): 194.

12 Martinez-Darve/Mata, 1989: 193-198, quienes recuerdan oportunamente las menciones de De Dominici y Thieme/Becker, 1929: 53. También transcribe el documento Caro Quesada, 1992: 118-119.

13 Sobre el duque de Medinaceli, véase Croce, 1948: 266-267. Coniglio, 1967: 338-349. Staffieri, 1990: 23-33. Antonelli, 2012: 77. Domínguez Rodríguez, 2013.
} 
ción de 85 esculturas antiguas, que alcanzó la considerable suma de 5.280 reales de vellón. Resulta razonable pensar que buena parte de los materiales intervenidos correspondieran a la colección reunida un siglo antes por el III duque de Alcalá. A juzgar por el elenco reseñado, su trabajo no solo consistió en efectuar pequeñas reintegraciones siguiendo los criterios de restauración de la época, sino también en esculpir cabezas enteras y partes del cuerpo para reconstruir las estatuas que se situarían junto a los otros mármoles antiguos en las logias y los jardines. Así, en su memorial de trabajos, Lemico se refiere expresamente a "quattro figuras de cuerpo entero", "siete figuras de medio cuerpo", "catorze cabezas y medios cuerpos", "tres niños compuestos", "una figura de la Fuente", "otra figura del otro jardin", etc.

Nos encontramos, pues, ante un maestro con una singular competencia madurada en los obradores donde se ejecutaban esculturas modernas y al mismo tiempo se apuraban los conocimientos sobre la estatuaria del mundo antiguo. Pero, ¿quién era Domenico Lemico? ¿Cuál es su lugar en la historiografía napolitana? Su trayectoria artística se concreta en una sintética "fortuna" crítica suministrada por la fuente por excelencia de la historia del arte napolitano: las Vite de Bernardo de Dominici, que dedica a Lemico, o mejor dicho, Lenmico, un breve pero preciso "cameo" dentro de la vida de Lorenzo Vaccaro, como uno de los discípulos que a juicio del biógrafo merecía ser recordado:

Domenico Lenmico, essendo stato molto tempo sotto la direzione di Lorenzo, andò a Roma e fu scolaro di monsù le Gros e di Camillo Rusconi, e fece gran studii sotto la condotta di amenduni, ed osservò l'antico, laonde divenuto ancor egli valentuomo ajutò il maestro nella statua ch'ei fece del sant'Andrea per la chiesa di San Giovanni Laterana, ed ajutò le Gros nella statua di san Domenico, che anche fu collocata nella suddetta chiesa, e fece altri lavori in ajuto de' suddetti màestri, lavorando da sé poche cose. Ritornato poi in regno, fu condotto alla certosa di San Lorenzo la Padula, ove più statue di marmo egli condusse, e piacendogli sommamente quella religione ed il luogo, atto alla quiete dell'anima, volle vestir l'abito certosino, che di buona voglia gli fu dato da que' monaci in riguardo di sua virtù e de' suoi buoni costumi. Sicché vivendo esemplarmente in quel santo luogo, ed operando in servigio di sua religione le sue sculture, venne a morte in fresca età, con dispiacer di que' padri, da' quali era molto stimato ${ }^{14}$.

Con pocas y ajustadas palabras el biógrafo consiguió trazar un perfil preciso: su dilatada formación en el entorno de Lorenzo Vaccaro (1655-1706), exponente ilustre de la tradición tardobarroca napolitana, seguramente entre los años ochenta y noventa del siglo XVII; su paso a Roma - etapa casi obligada - por los obradores de Pierre Le Gros (1666-1719) y Camillo Rusconi (1658-1728) a finales de los años noventa, lo que supondría una ocasión propicia para perfeccionar el oficio junto a escultores de prestigio, que eran además refinados estudiosos de la estatuaria clásica; y la conclusión de una carrera en la cartuja de Padula, una de las más importantes de Europa, donde habría realizado muchas esculturas, para finalmente morir en "fresca" edad con aflicción de la comunidad. El Domenico Lenmico de De Dominici es sin lugar a dudas el Domingo Lemico de los documentos españoles.

Hace algunos años, un completo trabajo sobre la cartuja de Padula permitió a Concetta Restaino identificar en el cenobio una serie de esculturas de fuerte impronta vaccariana que habían permanecido en el anonimato, entre otras razones por la dispersión del patrimonio documental - por no hablar del artístico- que habían provocado las exclaustraciones napoleónicas ${ }^{15}$. El lenguaje estilístico de un homogéneo grupo de esculturas como el Ángel Custodio [fig. 1], el San Lorenzo [fig. 2], el San José, el San Juan Bautista o la Magdalena [fig. 3], labradas en una piedra local muy dura y difícil de trabajar, orientaba la cuestión hacia un artista formado en el taller de Vaccaro, que utilizaba con desenvoltura y familiaridad los modelos del maestro, seguramente a través de un repertorio de prototipos y dibujos que guardaba celosamente. El citado pasaje dedominiciano cerraba el círculo en torno a un problema crítico y al mismo tiempo abría nuevos

14 De Dominici, 1742-1745 (2003-2014), III, t. 2: 902-903.

15 Restaino, 1993; 2004. 


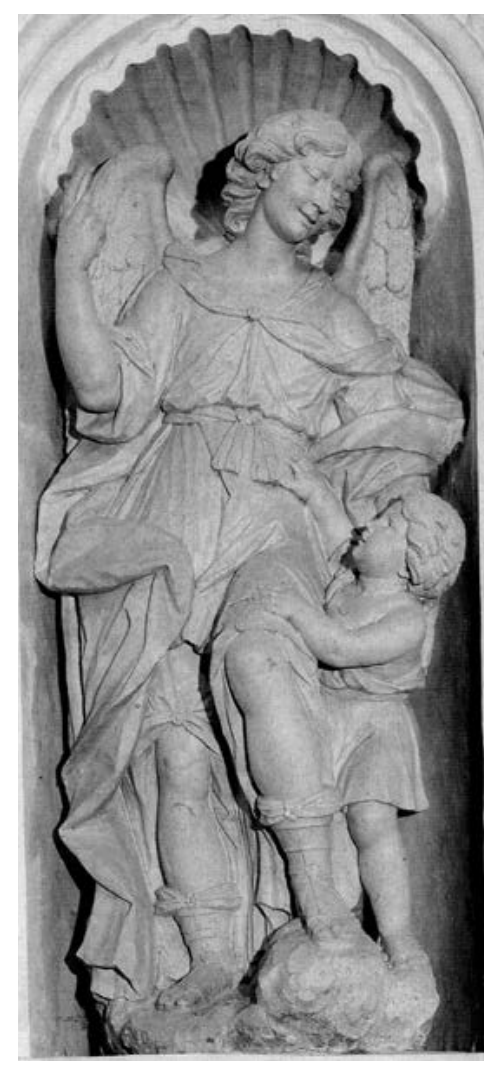

Fig. 1. Domenico Lemico.

Ángel Custodio.

Cartuja de Padula,

sala capitular.

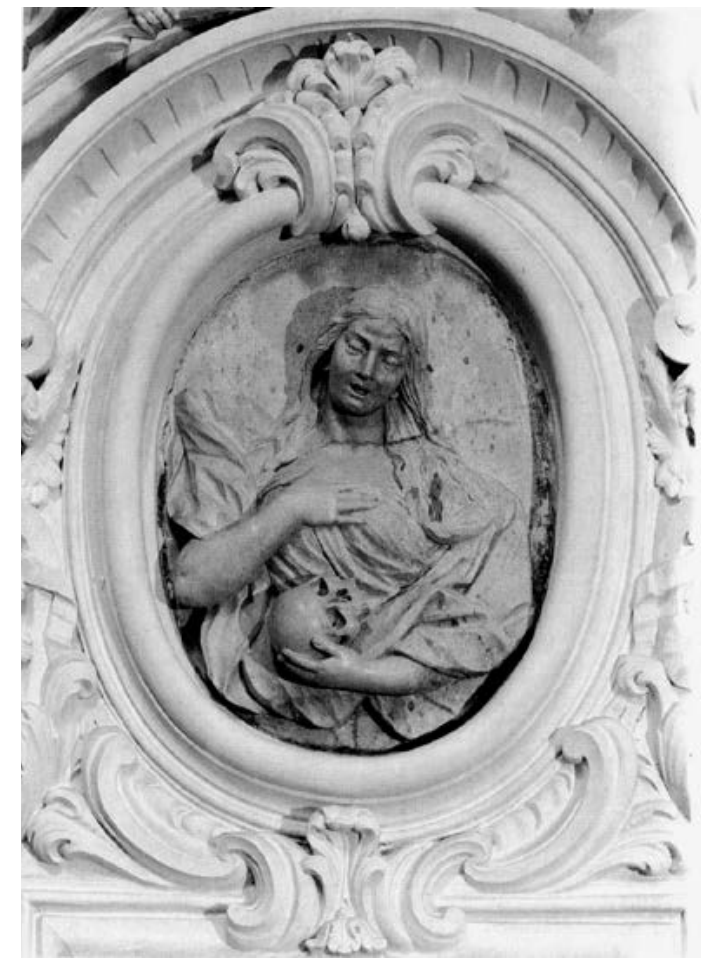

Fig. 3. Domenico Lemico. Magdalena. Cartuja de Padula, sala capitular.
Fig. 2. Domenico Lemico. San Lorenzo. Cartuja de Padula, sala capitular.

horizontes de investigación, especialmente a propósito de dos extraordinarias piezas de mármol de Carrara: los bustos del Ángel y la Virgen de la Anunciación, de elocuente impronta romana y matriz clasicista, ubicados en la iglesia de la Cartuja [fig. 4]. Ambos constituyen la mejor prueba formal de una experiencia directa con el ambiente de Le Gros ${ }^{16}$, como nos informa el biógrafo. El clasicismo barroco de ligero tono afrancesado que rezuma la Virgen, fluida y dulce, encerrada en su manto, testimonia una enorme calidad técnica que el empleo del mármol subraya, a diferencia de la piedra, más difícil de domesticar en el arremolinar de los paños y los pliegues flotantes. Sin embargo, su ternura, inspirada en el rostro del San Lorenzo, confirma las potencialidades expresivas de Lemico, que en el busto del Ángel, con su turgente y elegante movimiento de paños, juega con la doble lección de Vaccaro y Le Gros. Su rostro, por lo demás, sería la prueba definitiva de un sólido conocimiento de la escultura antigua.

16 Sobre Le Gros véase Bissel, 1997. 


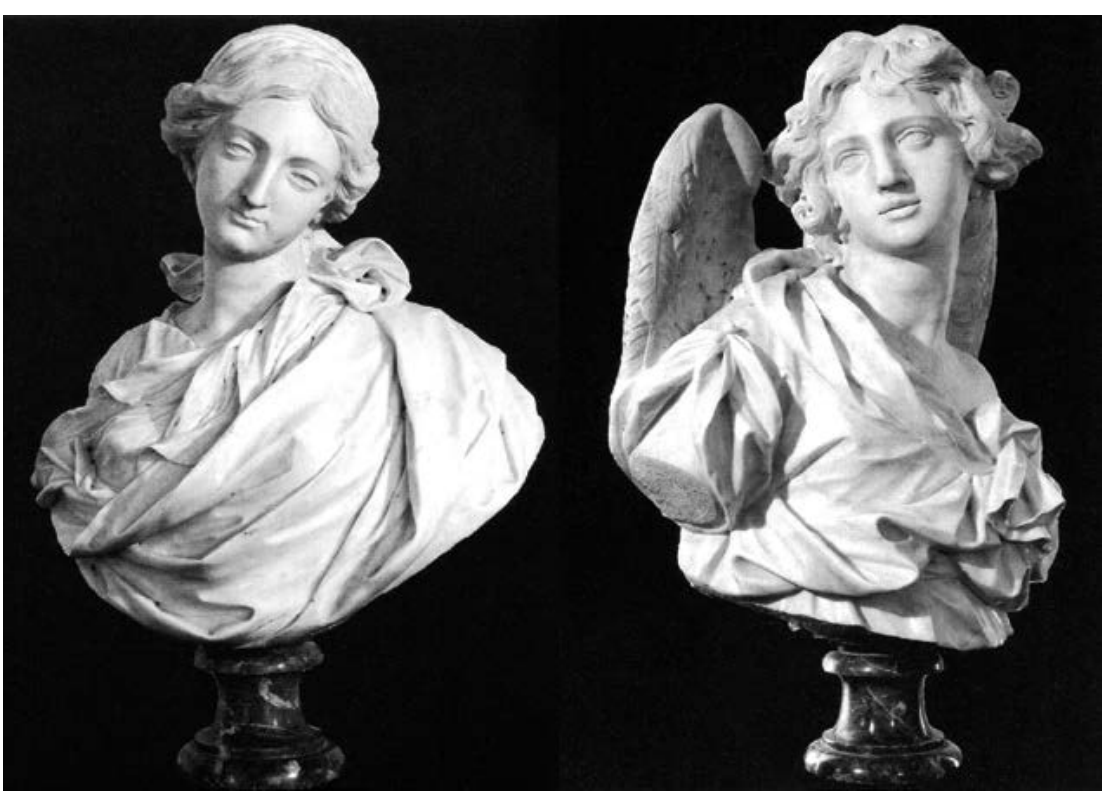

Fig. 4. Domenico Lemico. Anunciación. Cartuja de Padula, sala capitular.

Volviendo a Sevilla, en la Casa de Pilatos es posible realizar un par de precisiones cronológicas y estilísticas. Si en octubre de 1705 Lemico liquidaba el cobro, su trabajo ya habría culminado. Ello permite trabajar en la hipótesis de que el inicio de los trabajos hubiera comenzado en torno a 1702, el mismo año del retorno a España del duque de Medinaceli, quien bien pudo haberlo enrolado en su séquito para confiarle el cuidado de la colección de esculturas antiguas que poseía en su palacio sevillano ${ }^{17}$. De ser así, Medinaceli retomaría la tradición iniciada por su predecesor, quien había hecho venir hasta Sevilla al "napolitano" Tortelli y a un "veneciano", Marin Medenini Bellini, según las investigaciones de Lleó ${ }^{18}$. Examinando las obras con un criterio filológico podemos tratar de restituir a Lemico aquello que el tiempo ha separado, es decir, la actividad ibérica de la italiana. El estudio atento de las estatuas que hoy se conservan en la Casa de Pilatos lleva a reconocer la impronta estilística del maestro napolitano en un considerable número de piezas. Las que por el momento se pueden destacar son Pomona [fig. 5] y Tetis, dispuestas en la galería de entrada, y el Niño con paloma [fig. 6], que se ubica sobre la fuente del jardín. La cabeza de Pomona, pese al deterioro del material que está comprometiendo, entre otras partes, la nariz, presenta un movimiento y una inclinación de la cabeza más propias de un busto moderno. Sus características la acercan a las obras italianas de Lemico ya identificadas ${ }^{19}$, desde el modo de esculpir los mechones al sentido antiquizante que impregna la escultura, donde la lección de Le Gros parece más viva y palpitante que nunca. El rostro del niño que se yergue sobre la fuente con aire jocoso, mientras estrecha la paloma, retoma el modo de esculpir los rostros que se aprecia en otras esculturas presentes en la fachada pétrea de la cartuja de Padula. Pero hay más. Un singular busto femenino de la Casa de Pilatos [fig. 7] presenta una indudable afinidad estilística con los dos bustos de Padula [fig. 4]. Su vago berninismo, mitigado por el ablandamiento plástico de recuerdo clasicista, lo encontramos en un sentido análogo en la Virgen de la Anunciación.

${ }^{17}$ La comitiva ducal salió de Nápoles el 28 de febrero y tras pasar por París y Barcelona, entraría en Madrid el 3 de octubre de 1702. El duque se instaló en su palacio del Prado, primitiva residencia de Lerma. Domínguez Rodríguez, 2013: 33 у 219 .

${ }^{18}$ Lleó Cañal, 1984. Gaeta, 2004: 64

19 Naturalmente está por comprobar el alcance de su intervención sobre toda la colección de estatuas alojada en las logias y los jardines. Por el momento remitimos a dos estudios recientes en los que se identifican las estatuas antiguas y las restauraciones que éstas experimentaron en el quinientos: Trunk, 2002; 2003. 


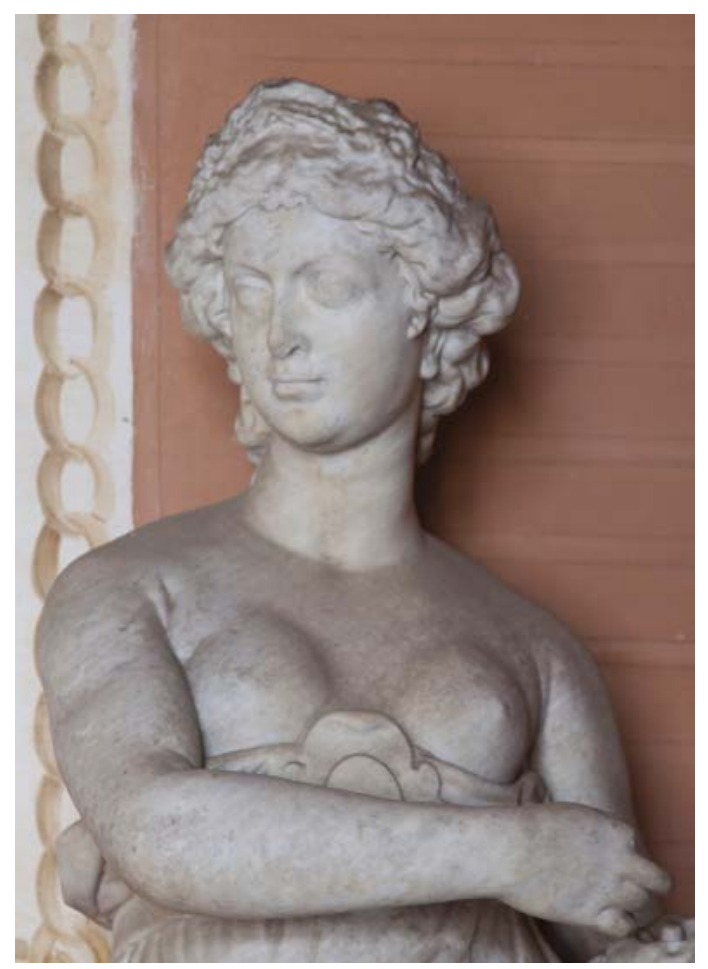

Fig. 5. Domenico Lemico (interviniendo sobre una estatua romana). Pomona. Sevilla, Casa de Pilatos.

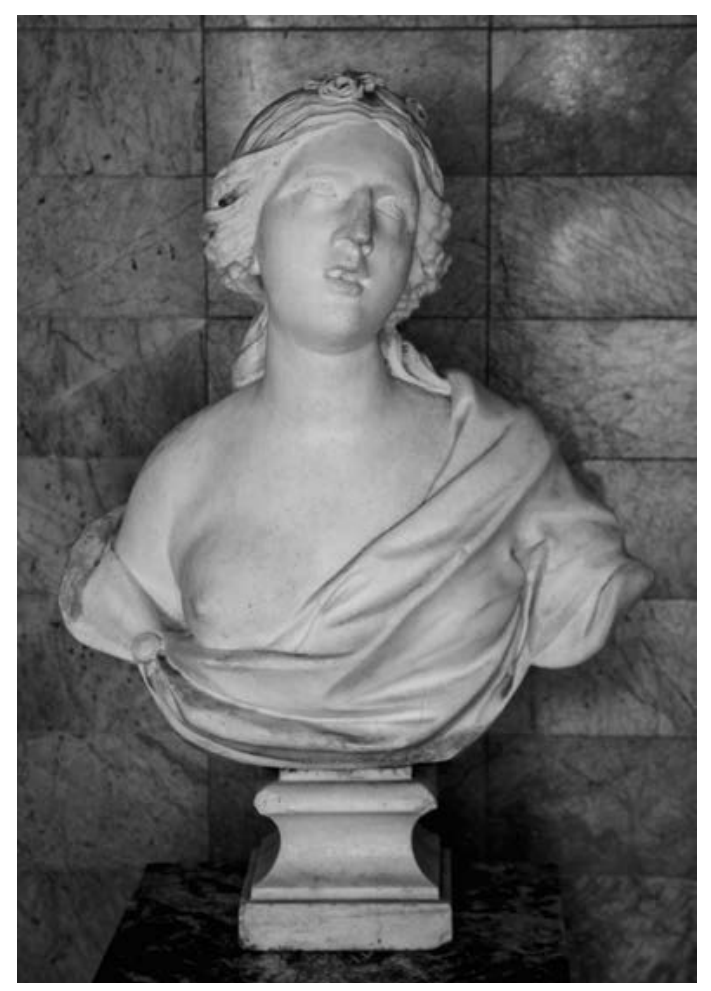

Fig. 7. Domenico Lemico. Busto femenino. Sevilla. Casa de Pilatos.

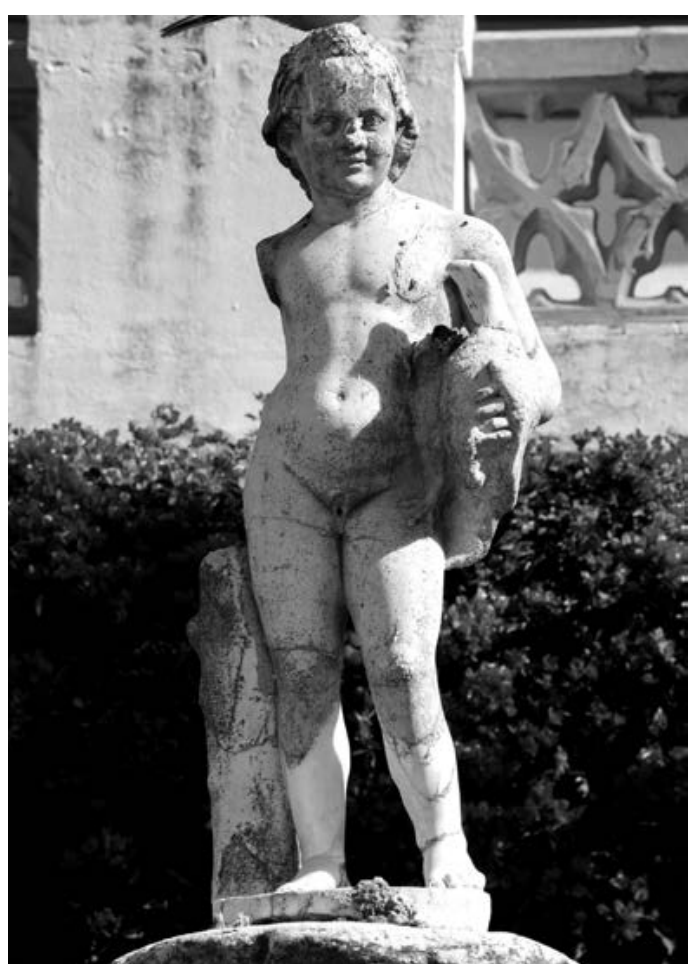

Fig. 6. Domenico Lemico (interviniendo sobre una estatua romana). Niño con paloma. Sevilla, Casa de Pilatos.

La sospecha de que Lemico no desempeñó un papel secundario en el contexto de la escultura andaluza de aquel momento viene confirmada por otro documento de archivo. En 1978, Taylor reveló la participación de nuestro escultor en la ejecución del sepulcro del cardenal y mitrado cordobés fray Pedro de Salazar (16301706), diseñado por el arquitecto lucentino Francisco Hurtado Izquierdo (1669-1725) como parte de la sacristía de la catedral de Córdoba [fig. 8$]^{20}$. El documento consiste en realidad en un cuaderno de jornales que deja poco margen a interpretaciones de naturaleza artística ${ }^{21}$, pero que nos informa del coste de un sepulcro de cierto porte, que requería el concurso de distintos materiales como el mármol y la piedra, cuya combinación cromática evocaría los prestigiosos modelos de los sepulcros papales y de otros ilustres eclesiásticos. Esta fuente requeriría de

20 Taylor, 1978: 21-22, aunque no hizo ninguna referencia a los orígenes napolitanos de Lemico. Sobre Hurtado, véase el clásico trabajo de Taylor, 1950.

${ }_{21}$ Cuentas segundas dadas por el señor don Miguel del Castillo de Escalera..., 1709-1710, Archivo de la Catedral de Córdoba (ACC), Leg. 839, s/f. 


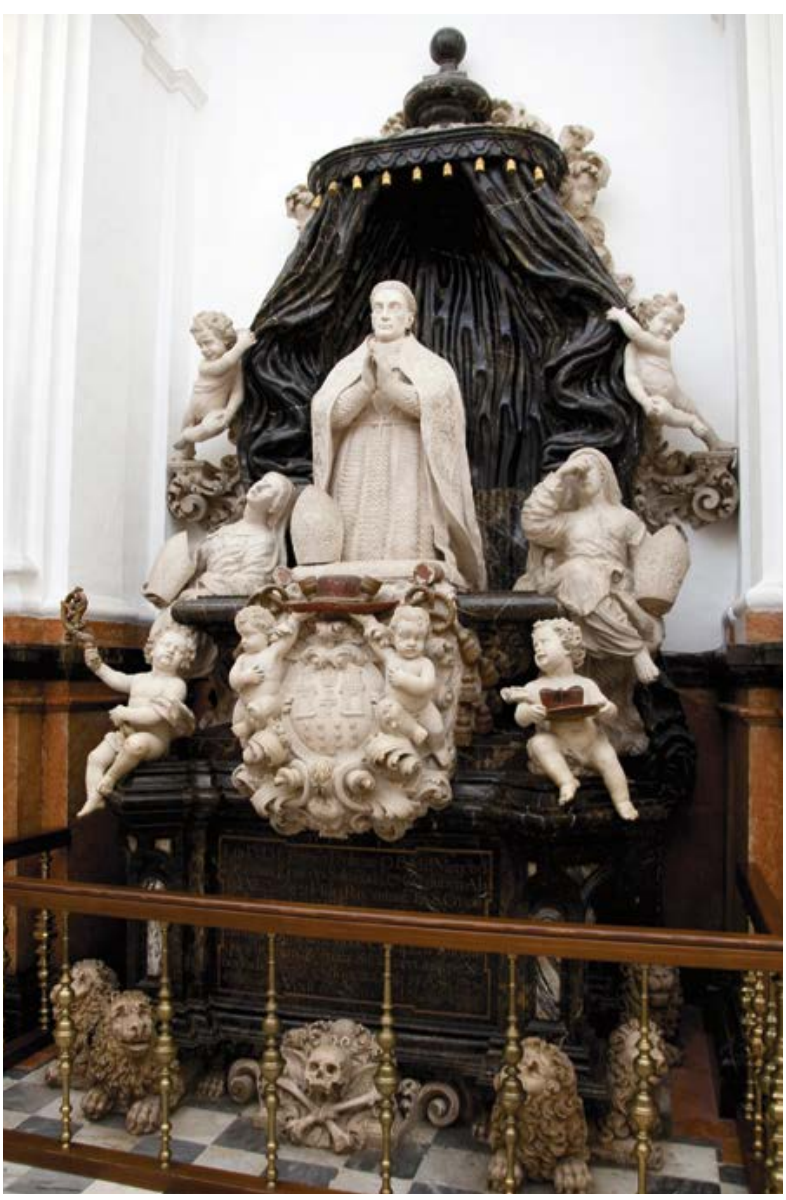

Fig. 8. Francisco Hurtado y otros. Sepulcro del cardenal don Pedro de Salazar. Catedral de Córdoba, sacristía.

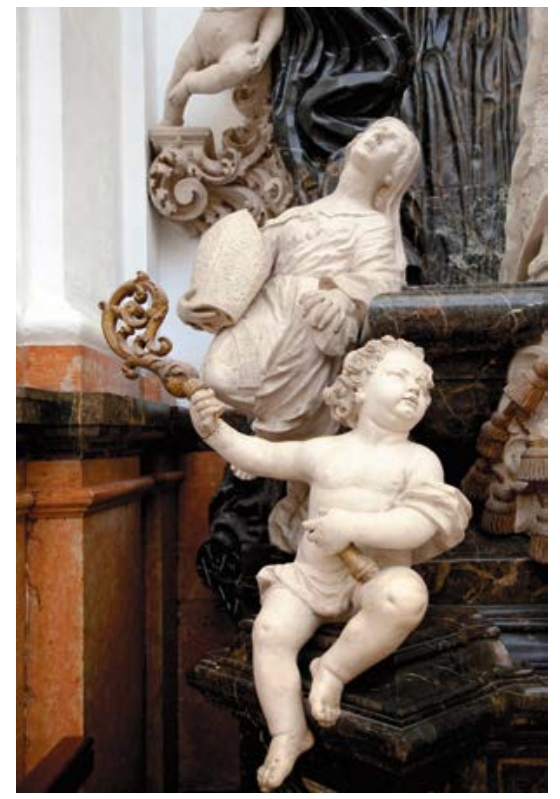

Fig. 9. Domenico Lemico. Ángel y virtud del sepulcro del cardenal Salazar. Catedral de Córdoba, sacristía. un análisis más exhaustivo, que permitiera afrontar una lectura de corte histórico-social, pero por el momento su transcripción íntegra nos ha permitido apurar la cronología de Lemico. Su nombre aparece registrado en las nóminas por algo más de un año, desde el 23 de marzo de 1709 hasta el 10 de mayo de 1710. A juzgar por los pagos, en una primera fase el napolitano debió desempeñar un rol preeminente respecto al otro escultor involucrado, Juan Prieto, pues respectivamente percibían un jornal de $10 \mathrm{y}$ 8 reales. Sin embargo, el predominio del napolitano sería breve, pues a partir de junio de 1709 se incorporó a la obra el ensamblador granadino Teodosio Sánchez de Rueda (1676-1730), que comenzó a percibir una compensación económica ligeramente superior a la suya (11 reales).

Gracias a la heterogeneidad técnica y formal del sepulcro, la mano de Lemico se puede reconocer con facilidad en los dos ángeles carnosos, de ascendencia vaccariana, que aparecen portando el báculo pastoral y el capelo cardenalicio [fig. 9]. A él deben corresponder también los modelos de las virtudes, que no obstante han sido víctimas de una ejecución descuidada, sobre todo en los paños, aunque sus rostros se pueden relacionar con el óvalo de la Magdalena esculpido en piedra en la car- 
tuja de Padula [fig. 3]. El lejano eco del monumento funerario del papa Gregorio XV realizado por Le Gros, sobre todo en lo que respecta al fondo textil, permite suponer que Lemico pudo haber aportado alguna idea al proyecto, que en cualquier caso quedó como un recuerdo borroso de los potentes modelos romanos que Francisco Hurtado solo pudo conocer a través de los repertorios gráficos ${ }^{22}$.

Aunque son todavía muchas las incógnitas que subsisten sobre la actividad española de Lemico, por el momento hemos contribuido a acotar su estancia en Andalucía entre 1702 y 1710 , sin descartar que en este tiempo el artista hubiera realizado viajes de corta duración al reino napolitano.

\section{De Venecia a Sevilla: Domenico Grasselli, escultor en piedra y en barro}

La instalación de Domenico Lemico en Sevilla vino prácticamente a coincidir con la llegada a la ciudad de otro escultor italiano, Domenico Grasselli, que aparece indistintamente citado en la documentación española como Domingo Graseli o Grazeli. El análisis de fuentes inéditas, como su expediente matrimonial y algunas partidas sacramentales, nos permiten ahora desvelar sus verdaderos orígenes y reconstruir su trayectoria andaluza. En el aludido expediente, Grasselli afirma ser hijo de un padre homónimo y de Clara Brageza, y ser natural de "la ciudad y arzobispado de Benensia [sic]", que abandonó con 24 años para marchar a Sevilla ${ }^{23}$. Si su testimonio es ajustado a la verdad, el escultor debió de nacer en la Serenissima en torno a 1679, y su traslado a la capital hispalense se produciría hacia 1703. Nada sabemos, por el momento, sobre su primera formación, ni si disfrutó de un soggiorno romano como Lemico, pues, a diferencia de éste, su nombre ha pasado por completo inadvertido en la historiografía italiana.

Esta laguna nos lleva a plantearnos un doble interrogante de partida: ¿pudieron conocerse Lemico y Grasselli en Italia? ¿Lo hicieron en Sevilla? Por el momento, ninguna de las dos preguntas tiene fácil respuesta, pues no disponemos de pruebas documentales que vinculen de forma directa a ambos escultores. Tampoco sabemos cuáles fueron las verdaderas motivaciones que llevaron a Grasselli a abandonar su patria para asentarse en España, en un momento de franca inestabilidad como el generado por la guerra de Sucesión al trono. A priori, su partida desde Venecia permitiría descartar cualquier vínculo con el retorno del duque de Medinaceli tras el virreinato napolitano. Lo más probable es que lo empujara un deseo de prosperar económicamente, siguiendo el camino de otros tantos artistas de discreto talento que, incapaces de progresar en un medio tan competitivo como el italiano, buscaron acomodo en el extranjero, aprovechando el prestigio que podía reportarles un apellido italiano.

En el caso de Grasselli, sus contactos con la comunidad hispana en Venecia debieron alimentar sus expectativas profesionales sobre España. Conocemos las identidades de dos de estos personajes porque años más tarde participarían como testigos en el mencionado expediente matrimonial. El primero, Pedro Sánchez, había recalado en Venecia hacia 1691, cuando todavía era un muchacho de catorce años. Luego volvería a coincidir con Grasselli en Sevilla, adonde marchó en 1705, trabajando en el ámbito de la impresión como fundidor de letra.

El otro español era un cantero llamado Nicolás Ortiz, que a finales del siglo XVII había estado en Venecia como miembro de la armada. Seguramente fue él quien convenció a Grasselli para emprender la aventura ibérica, pues sabemos que ambos viajaron juntos y llegaron a Sevilla hacia 1703. Si ya por entonces Ortiz trabajaba en el ámbito de la cantería, es posible que tuviera acordado algún encargo en Sevilla que requiriera la colaboración de un escultor como Grasselli, especializado en la labra de materiales pétreos.

22 Taylor apuntó su semejanza con los monumentos funerarios de Bernini, pero parece más oportuno relacionarlo con el sepulcro de Gregorio XV.

${ }^{23}$ Expediente matrimonial de Domingo Graseli y Josefa Rodríguez, 8 de abril-27 de mayo de 1713, Archivo General del Arzobispado de Sevilla (AGAS), Vicaría General, Matrim. Ord., 1713, s/f. 
Sevilla saludaba al nuevo siglo en un contexto económico deprimido, con la actividad comercial estancada tras el traslado de la flota de galeones a Cádiz en 1679, y todavía tocada por la grave crisis demográfica que había supuesto la pavorosa epidemia de peste de mediados del XVII. Ciertamente la urbe no era ya el próspero puerto de Indias que había retratado Cervantes, pero el volumen de fundaciones conventuales que albergaba, su condición de sede de un poderoso arzobispado y el consolidado prestigio de sus talleres de escultura podían constituir un evidente reclamo para un escultor foráneo en busca de fortuna.

En aquel entonces acababa de ser designado para la mitra hispalense el cardenal don Manuel Arias y Porres (1638-1717), quien se destacó por su papel como promotor artístico. Nada más tomar posesión del cargo tuvo que afrontar la remodelación de las fachadas del Palacio Arzobispal que había iniciado su predesor, dotándolas de dos portadas pétreas a sur y poniente $^{24}$. Aunque la mano de Grasselli no se advierte en ellas, tal vez sí llegara a participar en la otra gran empresa artística que auspició del prelado: el extraordionario retablo mayor del Sagrario metropolitano, donde por primera vez se empleó el estípite a gran escala en la retablística hispalense. La construcción de esta colosal estructura lígnea corrió a cargo del arquitecto de retablos zamorano Jerónimo Balbás (ca.1673-1748) y del escultor Pedro Duque Cornejo (1678-1757), quien contó con la colaboración de otros maestros como José Montés de Oca y un enigmático artífice, que aparece denominado en la documentación de una forma un tanto vaga como el "escultor florentín" 25 . Este apelativo sugiere un origen florentino, o cuanto menos italiano. ¿Podría tratarse de nuestro escultor, de Lemico o de un tercer artista en liza? Por desgracia, la parquedad de las fuentes y la desaparición del retablo, a comienzos del siglo XIX, dejan esta incógnita en el aire.

Junto a esta hipotética colaboración en el retablo balbasiano, habría que valorar la posibilidad de que Grasselli hubiera trabajado a las órdenes de Domenico Lemico en la reparación de los mármoles de la Casa de Pilatos, teniendo en cuenta su constatada habilidad en el trabajo de la piedra y el común origen italiano de ambos escultores. En este sentido, no hay que pasar por alto que en su carta de pago el napolitano reconocía que la cantidad abonada comprendía su mano de obra, el coste de los materiales, y también el trabajo de unos "oficiales" que le habían asistido en su labor, sin que por desgracia llegara a concretar sus identidades ${ }^{26}$.

La primera aparición de Grasselli en los protocolos notariales de la ciudad se remonta al 15 de junio de 1710, cuando figura en la escritura de arrendamiento de una casa como fiador del pintor Manuel Ortiz, acaso hermano o familiar del mencionado cantero. El veneciano, que ya firma como "D. Domingo Grasselli", figura como vecino de la collación de San Juan de la Palma y es identificado profesionalmente como pintor $^{27}$. Aunque este extremo puede deberse a un yerro de pluma, tampoco sería de extrañar que el veneciano practicara este oficio, considerando lo proclive del mundo italiano a la formación multidisciplinar de los artistas.

La siguiente noticia nos traslada hasta la primavera de 1713, cuando Grasselli ya llevaba una década asentado en Sevilla. A comienzos de abril inició los trámites eclesiásticos para contraer matrimonio con Josefa Rodríguez, una joven natural de Sevilla. Ambos declararon ser feligreses de la parroquia de Santiago desde hacía cuatro años, algo que en el caso del contrayente se contradice con lo afirmado en el arrendamiento de $1710^{28}$. El enlace acabó celebrándose el 28 de mayo de 1713 en la calle Lanza, situada en las inmediaciones de dicha parroquia. Entre los testigos aparecen algunos amigos del matrimonio, como el mencionado pintor Manuel Ortiz ${ }^{29}$. El veneciano permanecería en esta collación de Santiago durante, al menos, dieciséis años, tiempo

\footnotetext{
${ }^{24}$ Falcón, 1997: 76-78, atribuyó las esculturas de esta portada a Duque Cornejo, juicio que no compartimos.

25 Romero Torres, 2014: 267-268.

26 Caro Quesada, 1992: 118.

27 Quiles, 1990: 98.

28 Véase nota 23. Además de los testigos citados más arriba, por parte del escultor comparecieron Miguel Delgado, maestro del arte de la seda, y Francisco de Cádiz, trabajador en la fábrica de tabaco.

${ }_{29}$ Archivo Parroquial de San Ildefonso y Santiago de Sevilla (APSISSe), Santiago, L. Desposorios 3, f. 133v (28V-1713). Según nota marginal, las velaciones tuvieron lugar en dicha parroquia el 24 de febrero de 1715.
} 
en el que seis de sus hijos recibirían las aguas en la pila bautismal de la iglesia parroquial: Ignacia $(1714)^{30}$, Agustín $(1717)^{31}$, María Joaquina $(1720)^{32}$, Gertrudis (1722) ${ }^{33}$, María Micaela $(1726)^{34}$ y Manuel Felipe $(1729)^{35}$.

Los trabajos de escultura monumental que Grasselli acomete a lo largo de la década de 1720 prueban su total imbricación en el medio artístico hispalense. El más antiguo documentado lo relaciona con el arquitecto diocesano Diego Antonio Díaz (1675-1748), a quien se había encomendado la reconstrucción de la fachada de la iglesia tardogótica de San Miguel, en Morón de la Frontera, que amenazaba ruina por el gran desnivel del terreno. Díaz aprovechó esta intervención para dotar al templo de una monumental portada con columnas salomónicas y estípites, ponderada por Sancho Corbacho como uno de los exponentes más logrados del barroco en la región ${ }^{36}$. Las labores de cantería ya se habían ultimado en 1722, cuando se encargaron a Grasselli catorce estatuas de barro cocido que dotarían a la nueva portada de un significado contrarreformista: una escultura de la Inmaculada, para la hornacina principal, otra del santo titular, para la hornacina superior, y un Apostolado que quedaría distribuido entre los nichos de las calles laterales y los remates de los soportes. Sabemos que las efigies fueron entregadas en octubre de aquel mismo año, y que dos años más tarde serían policromadas por el pintor Manuel Rodríguez $^{37}$. Actualmente, tan solo la imagen mariana y las esculturas del arcángel, San Pedro y San Pablo permanecen in situ; las diez restantes debieron ser retiradas de la fachada antes de 1914, cuando el arquitecto Adolfo Fernández Casanova las cita en dependencias parroquiales, perdiéndose con posterioridad su rastro ${ }^{38}$. Las esculturas conservadas acusan un notable deterioro, al haber perdido su policromía y en algún caso hasta las extremidades, pero nos dan una idea de las cualidades creativas de Grasselli, mucho más limitadas que las de Lemico. Así, llama la atención la acusada frontalidad de las efigies y el ondulante juego de paños que las anima, más propio de la tradición escultórica hispalense que de la cultura figurativa italiana. Pese a su modesta calidad, resultan de interés por cuanto acreditan la competencia técnica de Grasselli en el modelado de esculturas en terracota de gran formato, una modalidad de la escultura monumental que permitía abaratar notablemente los costes de ejecución y que contaba en Sevilla con los espectaculares precedentes bajomedievales de Lorenzo Mercadante de Bretaña y Miguel Perrín en las portadas de la catedral.

Durante esta época Grasselli también entró en contacto con el cantero Miguel de Quintana, con quien entabló una estrecha amistad, según evidencia el apadrinamiento en 1726 de una de las hijas del escultor por el cantero y su esposa ${ }^{39}$. Resulta razonable pensar que ya por entonces ambos artistas trabajaran juntos en la obra del Real Colegio de Mareantes de San Telmo, a las órdenes de Leonardo y Matías de Figueroa. Las investigaciones de Teodoro Falcón han demostrado que Quintana participó en la construcción del claustro principal desde 1723, donde se conservan bustos en altorrelieve de San Telmo y Santo Domingo y un estimable relieve de la Virgen del Buen Aire, presidiendo la portada de la capilla ${ }^{40}$. Como no se tiene constancia de que el cantero fuera competente en trabajos figurativos, cabe la posibilidad de que estas piezas sean obra de Grasselli. De lo que no cabe ninguna duda es que el escultor veneciano acabaría involucrado pocos años después en las obras de la portada, la más monumental del barroco hispalense [fig. 10]. Aunque los cimientos ya se habían colocado en 1724, no fue hasta el verano de 1730 cuando se reanudaron las obras, siguiendo ya una nueva traza atribuida a Matías de Figueroa.

\footnotetext{
30 APSISSe, Santiago, L. Bautismos 4, f. 10v (28-IV-1714).

31 APSISSe, Santiago, L. Bautismos 4, f. 30v (29-X-1717).

32 APSISSe, Santiago, L. Bautismos 4, f. 45r (25-III-1720).

33 APSISSe, Santiago, L. Bautismos 4, f. 56r (8-IX-1722).

${ }^{34}$ APSISSe, Santiago, L. Bautismos 4, f. 79r (15-IX-1726).

35 APSISSe, Santiago, L. Bautismos 4, fol. 95r (13-VI-1729).

36 Sancho Corbacho, 1952: 148-149.

37 Sancho Corbacho, 1952: 149.

38 Fernández Casanova, 1914: 5.

39 Véase nota 34.

40 Falcón, 1991: 116-117.
} 


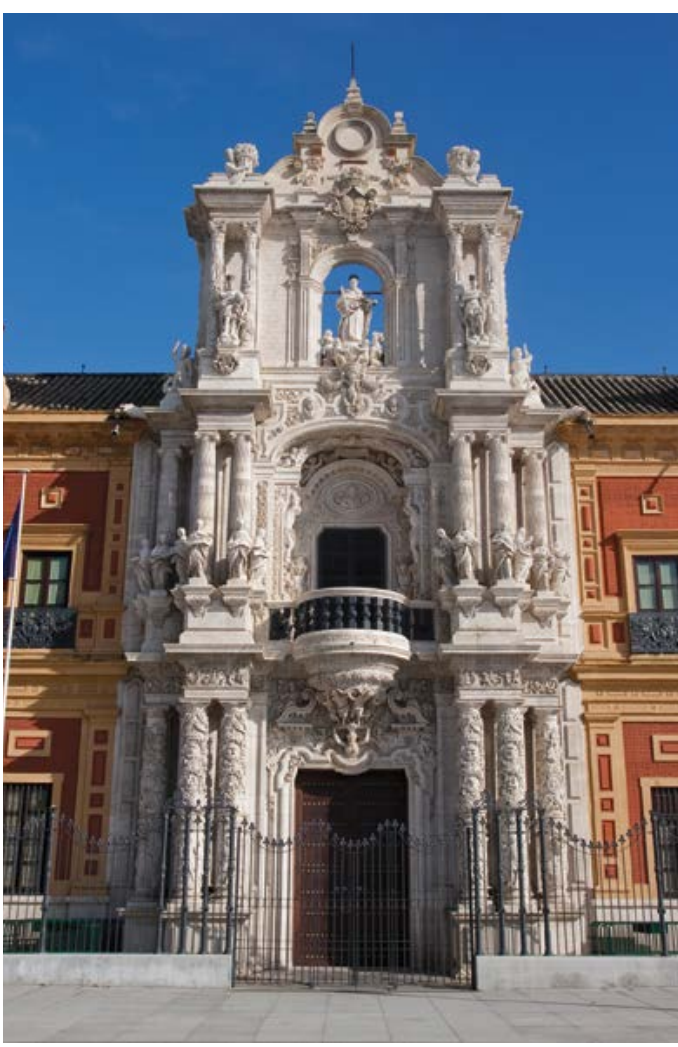

Fig. 10. Matías de Figueroa, Duque Cornejo y otros. Portada del Palacio de San Telmo. Sevilla.

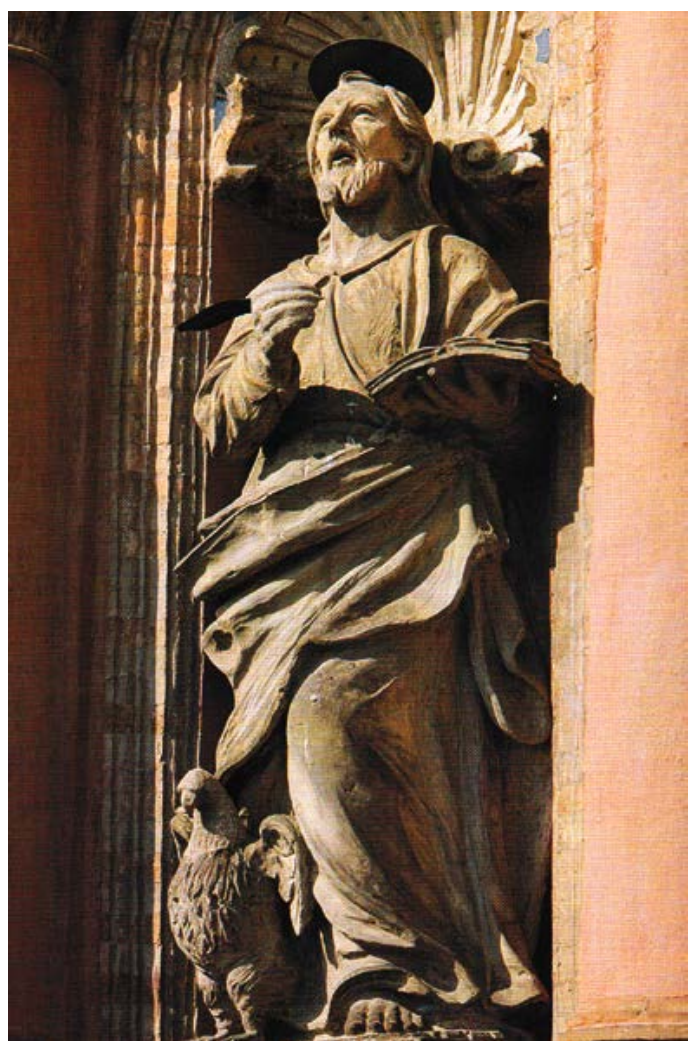

Fig. 11. Domenico Grasselli. San Juan Evangelista. Sevilla, Palacio de San Telmo, torre del claustro.

Falcón logró documentar la participación de Grasselli en la ejecución de la talla decorativa que tapiza el primer cuerpo de esta colosal estructura, pero resulta extremadamente difícil identificar su intervención toda vez que el veneciano trabajó en compañía de otros escultores sevillanos como Bartolomé García de Santiago, su hijo Manuel, Benito de Hita y Castillo y Diego Castillejo. La finalización de los trabajos del primer cuerpo a finales del verano de 1731 vino a coincidir con la entrada en escena de Duque Cornejo, que según parece despidió a todos los escultores a excepción de Grasseli y reclutó a Pedro Castillejo, su tío político ${ }^{41}$. Los cuerpos restantes de la portada se realizarían bajo la dirección de Cornejo hasta los últimos meses de 1733. El nieto de Roldán se reservó para sí la talla de algunos elementos singulares — como el repisón de indios tenantes, el San Fernando y el San Hermenegildo - delegando en el tándem Grasselli-Castillejo la concreción material del resto del elenco figurativo, que acusa una inferior calidad ejecutiva pese a estar realizado bajo los modelos y supervisión del maestro. Esta circunstancia dificulta nuevamente la identificación de los trabajos pétreos del veneciano, pero no ocurre lo mismo con cuatro esculturas en terracota que presumiblemente realizó en solitario. Nos referimos a los Evangelistas que se distribuyen dos a dos en las hornacinas de las torres del claustro, por las que se le pagaron 64 pesos de plata en mayo de $1734^{42}$. Al igual que el grupo de Morón, son obras algo faltas de proporción y discreto carácter, sobresaliendo únicamente la escultura de San Juan Evangelista, que en la configuración de su rostro acusa un evidente impacto de la plástica de Duque Cornejo [fig. 11].

${ }^{41}$ Falcón, 1991: 128-133. García Luque, 2017-2018: 630-637.

42 Falcón, 1991: 121. 
Fig. 12. Domenico Grasselli. Virgen de la Merced entre dos cautivos. Museo de Bellas Artes de Sevilla, portada.

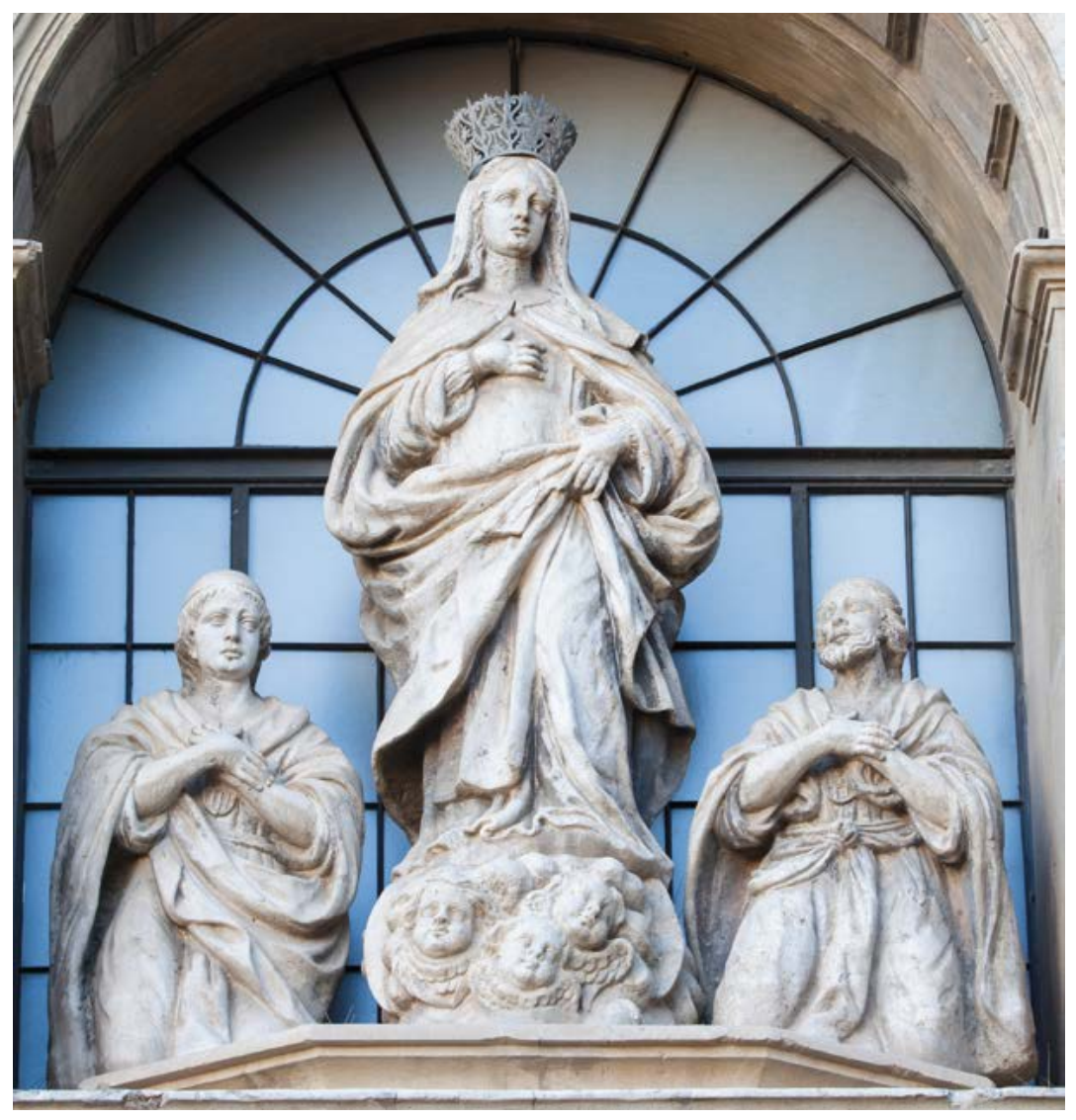

Esta deuda estilística se justifica fácilmente como consecuencia de la colaboración entre Cornejo y Grasselli en las obras de la portada de San Telmo. Sin embargo, es posible que ambos hubieran colaborado poco tiempo antes en otra portada sevillana: la de la iglesia del convento de la Merced Calzada, que justamente había contratado el cantero Miguel de Quintana en marzo de 1729, para realizarla en mármol y piedra de Martelilla con un coste de 16.000 reales $^{43}$. Como es bien conocido, el cenobio pasó a ser Museo Provincial de Bellas Artes tras la exclaustración, y la portada sería reaprovechada en la nueva fachada neobarroca que se construyó en 1945. En el nicho de su segundo cuerpo aún se conserva la escultura de la Virgen de la Merced sobre una peana de querubes, flanqueada por dos cautivos genuflexos y en actitud adorante, en alusión a la labor redentora de la orden mercedaria [fig. 12]. La huella de Duque Cornejo en este grupo es especialmente significativa a nivel compositivo, sobre todo en el caso de la Virgen, cuya silueta fusiforme y el tratamiento ampuloso del manto parecen preludiar la serie de las Alegorías de las Artes y las Ciencias que se distribuye en el segundo piso de la portada de San Telmo. Esta afinidad ha llevado a Falcón a atribuir el conjunto a Duque Cornejo ${ }^{44}$, aunque el modelado de la superficie y la fisionomía de los rostros ofrecen un parentesco más acusado con las pocas obras de Grasselli que se tienen documentadas. Si a esto sumamos la certeza de que Quintana fue el contratista de la obra, todo hace pensar que el veneciano fue el autor material del grupo figurativo, sin descartar que hubiera mediado algún modelo o dibujo de Duque Cornejo.

En algún momento de la década de 1730 Grasselli se trasladaría a Cádiz, tal vez animado por la necesidad de escultores en piedra que demandaba la obra de la Catedral Nueva, y quien sabe

43 Mendioroz Lacambra, 1989.

44 Falcón, 2011: 234; 2014: 280. 
si empujado por una falta de expectativas laborales en Sevilla, donde el taller de Duque Cornejo comenzaba a monopolizar el mercado escultórico. Pleguezuelo barajó ambas circunstancias como posibles desencadenantes de la marcha del escultor portugués Cayetano de Acosta (1709-1778) a la ciudad gaditana en torno a $1738^{45}$, y no tendría nada de particular que ambos escultores hubieran emprendido juntos el camino, puesto que en julio de ese mismo año ambos aparecen trabajando en el Hospital de Nuestra Señora del Carmen, conocido popularmente como "Hospital de Mujeres", que entonces se estaba levantando bajo trazas del arquitecto Pedro Luis Afanador. Las nóminas son en extremo escuetas y dificultan con mucho la identificación de manos, aunque Pleguezuelo ha barajado que pueda ser obra de Grasselli una escultura en mármol de la Virgen del Carmen, que se exhibe en una hornacina de la escalera, sobre un escudo de la orden carmelitana esculpido por Acosta ${ }^{46}$. La hipótesis resulta, desde luego, sugerente, aunque de ser obra suya sorprendería la pluralidad de registros del veneciano, que trabajaría aquí bajo unas coordenadas clasicistas no manifestadas en sus escasas obras documentadas.

Acosta permaneció en Cádiz durante toda la década de 1740, pero es seguro que Grasselli ya estaba de vuelta en Sevilla antes de 1743. Nos lo confirma una carta enviada en este año por don Ginés Hermosa y Espejo, asistente de la ciudad, en respuesta a una requisitoria remitida desde la Corte donde se buscaban escultores que pudieran trabajar en la obra del nuevo Palacio Real. Entre los que entonces estaban activos en Sevilla, el asistente se refirió expresamente a Grasselli como un maestro «de buena havilidad para el trabajo de estatuas de piedra», aunque curiosamente erró en su nacionalidad al señalarlo como flamenco ${ }^{47}$. Más allá de la anécdota, el hecho testimonia que el escultor, ya sexagenario y después de cuatro décadas en España, aún era considerado un foráneo en su ciudad adoptiva, donde probablemente conocería la muerte en un momento aún por determinar.

\section{BIBLIOGRAFÍA}

Albarrán Martín, Virginia (2008): “Se buscan escultores para el nuevo Palacio Real de Madrid”. En: Boletín del Seminario de Arte y Arqueología, 74, pp. 203-218.

Alonso Moral, Roberto (2007): "La scultura lignea napoletana in Spagna nell'età del barocco: presenza e influsso". En: Sculture di età barocca tra Terra d'Otranto, Napoli e Spagna. Roma: De Luca, pp. 75-86.

Alonso Moral, Roberto (2015): "Fama y fortuna de Nicola Fumo en España. Obras y comitentes". En: Sculture e intagli lignei tra Italia meridionale e Spagna, dal Quattro al Settecento. Nápoles: Paparo, pp. 95-104.

Alonso Moral, Roberto (2017): "Un mapa de la escultura italiana en España durante el Seicento". En: Scultura in legno policromo d'età barocca. La produzione di carattere religioso a Genova e nel circuito dei centri italiani. Genova: De Ferrari, pp. 619-637.

Antonelli, Attilio (ed.) (2012): Cerimoniale del viceregno spagnolo e austriaco di Napoli, 1650-1717. Soveria Mannelli: Rubbettino.

Bissell, Gerhard (1997): Pierre Le Gros 1666-1719. Reading: Si Vede.

Borrelli, Gennaro (1970): Il presepe napoletano. Roma: De Luca.

Borrelli, Gian Giotto (2005): Sculture in legno di età barocca in Basilicata. Nápoles: Paparo.

Caro Quesada, María Salud (1992): Noticias de escultura 1700-1720. Sevilla: Guadalquivir.

Casciaro, Raffaele (2007): "Seriazione e variazione: sculture di Nicola Fumo tra Napoli, la Puglia e la Spagna". En: Scultura meridionale in età moderna nei suoi rapporti con la circolazione mediterranea. Lecce: Congedo, vol. II, pp. 245-280.

Casciaro, Raffaele (2011): "Fortuna critica della scultura barocca napoletana in legno: qualche osservazione e l'avvio di un catalogo ragionato". En: Studi medievali e moderni, 29, pp. 273-298.

Casciaro, Raffaele/Cassiano, Antonio (eds.) (2007): Sculture di età barocca tra Terra d'Otranto, Napoli e Spagna. Roma: De Luca.

Checa Cremades, Fernando (dir.) (2001): El coleccionismo de escultura clásica en España. Madrid: Museo del Prado.

Coiro, Luigi (2011): “Adoperato da varii viceré nell'opere che dalla Spagna venivano commesse: qualche proposta per Aniello Perrone”. En: Kronos, 14, pp. 191-202.

\footnotetext{
45 Pleguezuelo Hernández, 2007: 35.

46 Pleguezuelo Hernández, 2007: 96. El escultor aparece denominado como "Domingo Braselli".

47 Albarrán Martín, 2008: 210.
} 
Coiro, Luigi (2017): "Fortune spagnole della scultura napoletana in legno, il caso del San Miguel di Nicola Fumo nella collezione Güell a Barcellona". En: Locus amoenus, 15, pp. 105-115.

Coniglio, Giuseppe (1967): I vicerè spagnoli di Napoli. Nápoles: Fiorentino.

Croce, Benedetto (1948): Storie e leggende napoletane. Bari: Laterza.

De Dominici, Bernardo [1742-45 (2003-2014)]: Vite de' pittori, scultori ed architetti napoletani [ed. de Sricchia Santoro, Fiorella/Zezza, Andrea]. Nápoles: Paparo.

Di Liddo, Isabella (2008): La circolazione della scultura lignea barocca nel Mediterraneo. Napoli, la Puglia e la Spagna. Una indagine comparata sul ruolo delle botteghe: Nicola Salzillo. Roma: De Luca.

Domínguez Rodríguez, José María (2013): Roma, Nápoles, Madrid. Mecenazgo musical del duque de Medinaceli, 16871710. Kassel: Reichenberger.

Estella Marcos, Margarita M. (1973): “Algunas esculturas en marfil italianas en España”. En: Archivo Español de Arte, 181, pp. 13-34.

Estella Marcos, Margarita M. (1976): “Tres obras de Nicolás Fumo, de paradero actual desconocido". En: Archivo Español de Arte, 193, pp. 80-85.

Estella Marcos, Margarita M. (2007): “La escultura napolitana en España: comitentes, artistas y dispersión”. En: Scultura meridionale in età moderna nei suoi rapporti con la circolazione mediterranea. Lecce: Congedo, vol. II, pp. 93-122.

Estella Marcos, Margarita M. (2015): "El relicario de las Agustinas de Salamanca”. En: Sculture e intagli lignei tra Italia meridionale e Spagna, dal Quattro al Settecento. Nápoles: Paparo, pp. 51-64.

Falcón, Teodoro (1991): El palacio de San Telmo. Sevilla: Gever.

Falcón, Teodoro (1997): El Palacio Arzobispal de Sevilla. Córdoba: Cajasur.

Falcón, Teodoro (2011): "Leonardo de Figueroa". En: Proyecto Andalucía. Artistas andaluces y artifices del arte andaluz, t. XXXV. La Coruña: Publicaciones Comunitarias, pp. 203-255.

Falcón, Teodoro (2014): "La portada principal del Palacio de San Telmo de Sevilla: nuevas aportaciones e interpretaciones". En: Diálogos de Arte. Homenaje al profesor Domingo Sánchez-Mesa Martín. Granada: Universidad, pp. 277-290.

Fernández Casanova, Adolfo (1914): "La iglesia parroquial de San Miguel Arcángel de Morón de la Frontera”. En: Revista de Morón, I, pp. 4-5.

Gaeta, Letizia (2004): “Ancora su Benvenuto Tortelli e gli altri tra concorrenza, collaborazioni e prezzi”. En: Kronos, 7, pp. 57-79.

Gaeta, Letizia (ed.) (2007a): Scultura meridionale in età moderna nei suoi rapporti con la circolazione mediterranea. Lecce: Congedo.

Gaeta, Letizia (2007b): “... colorite e miniate al naturale: vesti e incarnati nel repertorio degli scultori napoletani tra Seicento e Settecento”. En: La statua e la sua pelle. Artifici tecnici nella scultura dipinta tra Rinascimento e Barocco. Lecce: Congedo, vol. II, pp. 199-220.

Gaeta, Letizia (2011): "Modelli, fonti e 'venerati' maestri nelle botteghe napoletane: spunti per riflessioni e revisioni”. En: Studi medievali e moderni, XV, 29, pp. 299-308.

García Luque, Manuel (2017-2018): Pedro Duque Cornejo: estudio de su vida y obra (1678-1757). Tesis doctoral inédita, Universidad de Granada.

Leone de Castris, Pierluigi (ed.) (2009): Sculture in legno in Calabria dal Medioevo al Settecento. Nápoles: Paparo.

Leone de Castris, Pierluigi (ed.) (2015): Sculture e intagli lignei tra Italia meridionale e Spagna, dal Quattro al Settecento. Nápoles: Paparo.

Lleó Cañal, Vicente (1984): “La obra sevillana di Benvenuto Tortello”. En: Napoli Nobilissima, XXIII, pp. 198-207.

Lleó Cañal, Vicente [1998 (2017)]: La casa de Pilatos. Sevilla: Universidad de Sevilla.

Lleó Cañal, Vicente (2003): "Los usos de la antigüedad: colecciones arqueológicas en la España del Renacimiento". En: Reales Sitios, 156, pp. 30-43.

Lleó Cañal, Vicente (2017): “Benvenuto Tortello: arquitecto italiano en la Sevilla del Renacimiento". En: Napoli e la Spagna nel Cinquecento. Le opere, gli artisti, la storiografia. Galatina: Congedo, pp. 183-190.

López Jiménez, José Crisanto (1963): "El escultor Nicolás Salzillo". En: Boletín del Seminario de Estudios de Arte y Arqueología, 29, pp. 209-216.

López Jiménez, José Crisanto (1966): Escultura mediterránea. Final del siglo XVII y el XVIII. Notas desde el Sureste de España. Murcia: Caja de Ahorros del Sureste de España.

Martínez-Darve, Matilde/Mata, Josefa (1989): “Obras y reparaciones en la Casa de Pilatos durante el siglo XVIII". En: Archivo Hispalense, 221, pp. 193-200.

Mendioroz Lacambra, Ana (1989): "Miguel de Quintana, autor de la portada del convento de la Merced, actual Museo de Bellas Artes de Sevilla". En: Laboratorio de Arte, 2, pp. 261-266.

Pasculli Ferrara, Mimma (2007): "Da Nicola Salzillo di Santa Maria Capua Vetere a Francesco Salzillo di Murcia". En: Scultura meridionale in età moderna nei suoi rapporti con la circolazione mediterranea, vol. II. Galatina: Congedo, pp. 193-219.

Pleguezuelo Hernández, Alfonso (2007): Cayetano de Acosta (1709-1778). Sevilla: Diputación.

Quiles García, Fernando (1990): Noticias de pintura (1700-1720). Sevilla: Guadalquivir.

Restaino, Concetta (1993): "Certosa di San Lorenzo: acquisizioni di proposte". En: Archeologia e arte in Campania. Salerno: Società Dante Alighieri, pp. 173-200. 
Restaino, Concetta (2004): "Sugli aspetti artistici della Certosa di San Lorenzo. Acquisizioni, documenti, nuove attribuzioni”. En: Storia del Vallo di Diano. IV, La cultura artistica. Salerno: Laveglia, pp. 53-88.

Romero Torres, José Luis (2014): "Jerónimo Balbás, Pedro Duque Cornejo y otros artistas en el retablo mayor de la iglesia del Sagrario de Sevilla”. En: Diálogos de Arte. Homenaje al profesor Domingo Sánchez-Mesa Martín. Granada: Universidad, pp. 259-270.

Sancho Corbacho, Antonio (1952): Arquitectura barroca sevillana del siglo XVIII. Madrid: CSIC.

Santiago Páez, Elena (1967): “Algunas esculturas napolitanas del siglo XVII en España”. En: Archivo Español de Arte, 158 , pp. 115-132.

Staffieri, Gloria (1990): Colligite Fragmenta. La vita musicale romana negli “avvisi Marescotti" (1683-1707). Lucca: Libreria musicale italiana.

Taylor, René (1950): “Francisco Hurtado and his school”. En: The Art Bulletin, 32, pp. 25-61.

Taylor, René (1978): Arquitectura andaluza: los hermanos Sánchez de Rueda. Salamanca: Universidad.

Thieme, Ulrich/Becker, Felix (1929): Allgemeines Lexikon der bildenden Kunstler von der Antike bis zur Gegenwart unter mitwirkung von 300 Fachgelehrten des in-und auslandes, vol. 23. Leipzig: E. A. Seemann.

Trunk, Markus (2002): Die "Casa de Pilatos" in Sevilla. Studien zu Sammlung, Aufstellung und Rezeption antiker Skulpturen im Spanien des 16. Jhs. Mainz: von Zabern.

Trunk, Markus (2003): "Early restorations of ancient sculptures in the Casa de Pilatos, Seville. sources and evidence". En: History of restoration of ancient stone sculptures. Los Angeles: J. Paul Getty Museum.

Fecha de recepción: 30-III-2019

Fecha de aceptación: 03-VII-2019 